\title{
Character Strength Pada Atlet Penyandang Tuna Daksa Di NPCI (National Paralympic Committee Indonesia) Kota Padang
}

\author{
Rizqa Amalia Hendri, Isna Asyri Syahrina, Andhika Anggawira \\ Fakultas Psikologi, Universitas Putra Indonesia "YPTK" Padang, Indonesia \\ Email: Rizqa.amalia1906@gmail.com Isnaasyrisrina@gmail.com anggawira4ever@yahoo.co.uk
}

\begin{abstract}
The purpose of this study was to describe the Character Strength on the physically disabled athletes in NPCI (National Paralympic Committee Indonesia) Kota Padang. The method used mix method which are combine both quantitative and qualitative approaches. Sampling in this study using purposive sampling technique. The sample in this study was 10 athletes with physical disabilities in NPCI Kota Padang. The measuring instrument used in this study is the character strength scale which is based on the classification of character strength, namely wisdom and knowledge, courage, humanity, justice, temperance and transcendence. Character strength can be seen from the measurement result using a scale consisting of 81 items in the form of a likert scale. After that, an interview was conducted with the subject to identify more deeply related to their character strength. The result of measurements and interviews show that athletes with physical disabilities in NPCI Kota Padang have five character strength. The five character strength are appreciation, spirituality, hope, gratitude and vitality.
\end{abstract}

Keywords $\quad$ : Character strength, athletes and physical disabilities

\begin{abstract}
Abstrak
Tujuan dari penelitian ini adalah untuk menggambarkan Character strength pada atlet penyandang tuna daksa di NPCI (National Paralympic Committee Indonesia) Kota Padang. Dalam penelitian ini hanya terdapat satu variabel (variabel tunggal) yaitu character strengths. Pendekatan yang digunakan dalam penelitian ini berupa metode campuran atau metode deskriptif yaitu antara pendekatan kuantitatif dan kualitatif. Pengambilan sampel pada penelitian ini menggunakan teknik purposive sampling. Sampel dalam penelitian ini adalah 10 orang atlet penyandang disabilitas tuna daksa di NPCI Kota Padang. Alat ukur yang digunakan pada penelitian ini adalah skala character strength yang dibuat berdasarkan klasifikasi character strength yaitu kearifan dan pengetahuan, keteguhan hati, kemanusiaan dan cinta kasih, keadilan, kesederhanaan, transendensi.Character strength dilihat dari hasil pengukuran menggunakan skala yang terdiri dari 81 item dalam bentuk skala likert. Setelah itu dilakukan interview terhadap subjek untuk mengenali lebih mendalam terkait dengan kekuatan karakternya. Hasil pengukuran dan wawancara menunjukkan Atlet penyandang Tuna daksa di NPCI Kota Padang memiliki lima Character Strength. Kelima character strength tersebut adalah apresiasi, spiritualitas, harapan, rasa syukur dan vitalitas.
\end{abstract}

Kata kunci $\quad$ : Character Strength, atlet dan penyandang tuna daksa.

\section{Pendahuluan}

Manusia yang lahir di dunia tidak semuanya memiliki fisik yang lengkap, kadangkala ada manusia yang terlahir di dunia dengan kondisi fisik yang kurang atau tidak normal. Ketidaksempurnaan fisik tentunya seringkali menjadi sebuah hambatan bagi seseorang untuk melakukan berbagai aktifitas sehari-hari. Salah satu bentuk dari ketidaksempurnaan fisik adalah gangguan atau kerusakan pada tulang dan otot yang lebih sering disebut dengan istilah Tuna daksa [1].

Menurut Global Burden of Disease pada tahun 2004 memperkirakan bahwa 15,3\% dari penduduk dunia sekitar 978 juta dari 6,4 miliar penduduk memiliki kecacatan sedang atau parah, sementara 2,9\% atau sekitar 185 juta penduduk memiliki kecacatan parah [2]. Lauster [3], menyatakan bahwa perlakuan dan pandangan negatif dari masyarakat kepada para penyandang cacat menyebabkan para penyandang cacat mengalami kurang percaya diri, minder, dan merasa tidak berguna. Seiring berjalannya waktu pada masa sekarang ini, peran setiap individu mulai mendapatkan perhatian dari masyarakat dunia.

Dalam InfoDatin [3], PBB menetapkan tanggal 3 Desember sebagai Hari Penyandang Cacat Sedunia dimana hari ini merupakan momentum bagi masyarakat internasional untuk memperhatikan dan menyelesaikan persoalan yang dihadapi para penyandang disabilitas.

Saat ini, keterbatasan fisik tidak lagi menjadi halangan bagi penyandang cacat untuk dapat menggapai cita-cita maupun masih tetap dapat berkreasi dan berprestasi serta berkompetisi didalam kehidupan ini. Banyak cara yang ditempuh untuk membuktikan eksistensi para penyandang cacat, selain bidang seni ada juga bidang olahraga [4].

Diterima Redaksi: 1-11-2020 | Selesai Revisi: 08-2-2021 | Diterbitkan Online: 10-2-2021 
Untuk mewadahi kegiatan olahraga para penyandang cacat maka dibentuklah National Paralympic Committee Indonesia (NPCI). NPCI adalah organisasi pembina atlet penyandang disabilitas di Indonesia yang berada dibawah naungan Kementrian Pemuda dan Olahraga Republik Indonesia. Organisasi ini menyelenggarakan Pekan Paralimpiade Nasional (Peparnas). NPCI adalah satu-satunya wadah keolahragaan Penyandang Cacat Indonesia yang berwenang mengkoordinasikan dan membina setiap dan seluruh kegiatan olahraga prestasi penyandang cacat diseluruh wilayah hukum Republik Indonesia yang termasuk didalamnya adalah pembinaan pembangunan prestasi olahraga penyandang cacat dikota Padang yang dilakukan Oleh NPCI Kota Padang. Berbagai macam cabang olahraga bagi penyandang tuna daksa yang dibina dan dikembangkan oleh NPCI Kota Padang antara lain Atletik, Bulutangkis, Bowling, Renang, Catur, dan Sepak Bola. Penyandang tuna daksa juga bisa mengembangkan prestasi seperti menjadi seorang atlet disabilitas yang mampu berpartisipasi dalam meningkatkan dan memajukan olahraga, serta berprestasi dan mampu mengikuti olahraga Olimpiade Paralimpik (Paralympic Olimpiade) [5]. Atlet penyandang tuna daksa adalah orang yang mengikuti suatu pertandingan untuk mencapai suatu prestasi namun dengan kondisi fisik yang berbeda dan tidak sama dengan atlet normal pada umumnya dikarenakan suatu kelainan fisik akibat penyakit, kecelakaan atau bawaan dari lahir [5].

Ketika para atlet melakukan latihan dan pertandingan, mereka biasanya mendapatkan tuntutan-tuntuan baik itu dari pelatih, pengurus, dan pemerintah. Meskipun para atlet mengadapi banyak hal yang terkadang juga menjadi kendala bagi mereka, tetapi tidak serta merta membuat mereka mundur untuk menjadi seorang Atlet, mereka tetap bertahan dan selalu berusaha untuk mengatasi kendala yang ada, mereka juga menganggap hal tersebut merupakan konsekuensi yang harus di hadapi. Sebagian atlet memiliki pandangan bahwa keterbatasan fisik yang mereka miliki sebenarnya adalah sebuah karunia yang diberikan oleh Tuhan, oleh sebab itu mereka tidak menjadikan keterbatasan fisik sebagai hambatan dalam mencapai cita-cita yang di inginkan walaupun pada awalnya sering diliputi rasa malu dan minder[1].

Dalam penelitian tim Litbang KONI oleh Setyobroto[1] mengemukakan bahwa sifat-sifat kepribadian, faktor pembawaan dan pengaruh sekitar merupakan variabel yang memungkinkan seseorang mencapai prestasi tinggi dalam satu cabang olahraga. Berdasarkan hal tersebut dapat diasumsikan bahwa untuk menjadi seorang atlet yang berprestasi, hendaknya seorang atlet memiliki kekuatan dan karakter positif tertentu didalam dirinya.

Kekuatan karakter adalah pondasi positif dalam masa kehidupan yang masih muda dan grow strong and healthy (pertumbuhan yang kuat dan sehat) tidak akan tumbuh sehat dan kuat tanpa manajemen yang baik. Suatu usaha itu tidak akan tumbuh yang baik tanpa manajemen yang baik [6]. Konsep Kekuatan Karakter (Character Strength) pertama kali dikemukakan oleh Peterson dan Seligman. Kekuatan Karakter (Character Strength) merupakan karakter baik yang mengarahkan individu pada pencapaian kebajikan (Virtue), atau Trait positif yang terefleksi dalam pikiran, perasaan, dan tingkah laku. Karakter yang baik adalah kualitas dari individu yang membuat individu tersebut dipandang baik secara moral. Kekuatan-kekuatan tersebut membentuk satu konsep kebajikan (Virtue) yang sama, namun memiliki karakteristik yang berbeda-beda [7]. Seligman [1], individu dapat mencapai keberhasilan dan kepuasan emosional yang terdalam dengan menggunakan serta mengembangkan kekuatan khas dalam kehidupan sehari-hari, daripada berusaha keras untuk memperbaiki kelemahan. Dengan demikian Signature Strength yang dimiliki oleh para Atlet penyandang Tuna daksa membuat mereka mengambil keputusan untuk menjadi seorang atlet dan bertahan menghadapi berbagai macam kendala dan tuntuan yang ada serta berusaha sekuat tenaga memperoleh prestasi yang maksimal.

Berdasarkan wawancara awal yang dilakukan pada tanggal 17 Mei 2019, kepada salah satu anggota aktif dari NPCI kota Padang yang berinisial AI. AI merupakan salah satu atlet yang mendapatkan dua medali emas dalam cabang olahraga lempar lembing dan sepak takraw pada Pekan Paralimpik Daerah 2019. AI mengatakan bahwa AI merupakan salah satu penyandang tuna daksa yang disebabkan karena kecelakaan dan bukan bawaan lahir. AI mengalami patah tulang belakang yang mengakibatkan kelumpuhan pada bagian pinggul sampai kaki. AI juga pernah divonis hanya dapat bertahan hidup dalam waktu tiga bulan yang menyebabkan AI sempat putus asa dan menyerah. AI sempat merasa khawatir akan masa depannya dengan kondisinya yang menjadi disabilitas. Saat mengalami kecelakaan AI masih duduk dibangku kuliah semester empat. AI sempat mengalami denial (penolakan terhadap kondisinya) selama 5 tahun lamanya. Setelah itu AI mulai berusaha untuk beraktivitas, AI 
kembali memulai kuliahnya di universitas yang berbeda dari semester awal lagi dan AI juga berusaha mencari komunitas-komunitas yang mewadahi penyandang disabilitas seperti dirinya.

Peneliti juga melakukan wawancara pada tanggal 24 November 2019, dengan HP salah satu atlet dari cabang olahraga lari dikomunitas NPCI kota Padang. HP sekarang bekerja sebagai honorer di salah satu SLB Negeri di kota Padang. HP yang sekarang berusia 30 tahun merupakan penderita tuna daksa ringan. HP mengalami cacat fisik bawaan lahir yaitu kelainan pada system cerebral atau biasa disebut cerebral palsy. Dengan kondisinya, HP mengalami kesulitan untuk berkomunikasi dengan lancar sehingga kondisi ini menghambat HP dalam melakukan aktivitas dan bersosialisasi dengan orang lain. HP sering merasa minder untuk beraktivitas dengan orang-orang disekitarnya, karena keterbatasan yang dimilikinya. Itulah salah satu hal yang mendasari HP bergabung di komunitas NPCI, yaitu untuk mencari teman dan mencapai cita-citanya menjadi seorang atlet internasional.

\subsection{Character Strength}

Menurut Peterson dan Seligman [8] Character Strengths adalah unsur, proses, dan mekanisme psikologis yang memperjelas konsep virtues. Dengan kata lain, character strengths adalah rute-rute yang berbeda dalam mencapai suatu virtue atau virtue lainnya. Contohnya, wisdom (kearifan) dapat dicapai melalui beberapa character strengths seperti creativity (kreativitas), curiosity (keingintahuan), love of learning (kecintaan belajar), open mindedness (keterbukaan pikiran) dan perspective (perspektif). Character strengths tersebut di atas, memiliki kesamaan dalam hal meraih dan menggunakan ilmu pengetahuan tetapi juga memiliki perbedaan.

\subsection{Klasifikasi Character Strength}

Untuk dapat dikatakan sebagai character strengths, karakter positif harus memenuhi sebagian besar dari sepuluh kriteria yang ditetapkan [8], terdapat enam virtue atau kebaikan utama yang mencakup dua puluh empat kekuatan karakter yaitu :

a. Strengths of wisdom and knowledge (Kekuatan akan kebijaksanaan dan pengetahuan)

Dipahami sebagai kemampuan kognitif untuk sebuah keahlian dan ilmu pengetahuan yang menjadi landasan dalam proses mencapai kehidupan yang baik.

b. Strengths of courage (Kekuatan akan Keteguhan Hati)

Virtue keteguhan hati merupakan virtue kedua yang dipahami sebagai kemampuan emosi untuk mencapai tujuan, walaupun menghadapi tuntutan eksternal dan internal.

c. Strengths of Humanity (Kekuatan akan Kemanusiaan dan Cinta Kasih)

Kemanusiaan merupakan virtue ketiga yang dipahami sebagai sifat positif yang berwujud kemampuan menjaga hubungan interpersonal. Kemanusiaan adalah kemampuan untuk mencintai, berbuat kebaikan sehingga mampu beradaptasi dengan lingkungan. Awalnya dibangun melalui hubungan interpersonal yang kemudian meluas pada hubungan sosial.

d. Strengths of Justice (Kekuatan akan Keadilan)

Keadilan merupakan virtue keempat yang didefinisikan sebagai kemampuan untuk memperhatikan hak-hak dan kewajiban individu dalam kehidupan komunitas.

e. Strengths of Temperance (Kekuatan akan Pengendalian Diri)

Virtue kelima yang dikemukakan ini berkaitan dengan kemampuan untuk menahan diri dan tidak melakukan sesuatu yang dianggap berlebihan.

f. Strengths of Transcendence (Transendensi)

Transendensi merupakan kekuatan karakter terakhir yang dikemukakan oleh Peterson dan Seligman (2004), kekuatan karakter ini berkaitan dengan kemampuan menjalin hubungan dengan kekuatan semesta yang lebih besar serta dalam memaknai kehidupan individu tersebut.

\subsection{Karakteristik Tuna Daksa}

Selain klasifikasi tuna daksa, ada karakteristik tuna daksa. Karakteristik tuna daksa meliputi [9]:

a. Karakteristik akademik

Penyandang tuna daksa yang mengalami kelainan pada sistem otot dan rangka adalah normal sehingga dapat mengikuti pelajaran sama dengan individu normal, sedangkan penyandang tuna daksa yang mengalami kelainan pada sistem cerebral, tingkat kecerdasannya berentang mulai dari tingkat idiocy sampai dengan gifted.

b. Karakteristik Sosial atau emosional 
Karakteristik sosial atau emosional penyandang tuna daksa bermula dari konsep diri individu yang merasa dirinya cacat, tidak berguna, dan menjadi beban orang lain yang mengakibatkan mereka malas belajar, bermain dan membentuk perilaku yang salah. Kehadiran individu cacat yang tidak diterima oleh orang tua dan disingkirkan dari masyarakat akan merusak perkembangan pribadi seseorang. Kegiatan jasmani yang tidak dapat dilakukan oleh penyandang tuna daksa dapat mengakibatkan timbulnya masalah emosi, seperti mudah tersinggung, mudah marah, rendah diri, kurang dapat bergaul, pemalu, menyendiri, dan frustrasi.

c. Karakteristik Fisik atau Kesehatan

Karakteristik fisik atau kesehatan penyandang tuna daksa biasanya selain mengalami cacat tubuh adalah kecenderungan mengalami gangguan lain, seperti sakit gigi, berkurangnya daya pendengaran, penglihatan, dan gangguan bicara. Kelainan tambahan itu banyak ditemukan pada penyandang tuna daksa sistem cerebral.

Dapat ditarik kesimpulan bahwa terdapat tiga karakteristik dari tuna daksa yaitu karakteristik akademik, karakteristik sosial atau emosional dan karakteristik fisik atau kesehatan.

\section{Metode Penelitian}

Pendekatan yang digunakan dalam penelitian ini berupa metode campuran atau metode deskriptif yaitu antara pendekatan kuantitatif dan kualitatif. Ali [10], menjelaskan bahwa metode penelitian deskriptif digunakan untuk memecahkan sekaligus menjawab permasalahan yang terjadi di masa sekarang. Dilakukan dengan menempuh langkah-langkah pengumpulan klasifikasi dan analisis atau pengolahan data, membuat kesimpulan dan laporan dengan tujuan utama untuk menggambarkan tentang suatu keadaan secara objektif dalam suatu deskripsi. Kemudian, yang dimaksud dengan pendekatan kuantitatif adalah pendekatan yang digunakan dalam penelitian dengan cara mengukur indikatorindikator variabel penelitian sehingga diperoleh gambaran diantara variabel tersebut.

Dalam penelitian ini hanya terdapat satu variabel (variabel tunggal) yaitu character strengths. Pengambilan sampel pada penelitian ini menggunakan teknik purposive sampling. Sugiyono [11] purposive sampling adalah teknik pengambilan sampel sumber data dengan pertimbangan tertentu. Sampel dalam penelitian ini adalah 10 orang atlet penyandang disabilitas tuna daksa di NPCI Kota Padang. Alat ukur yang digunakan pada penelitian ini adalah skala character strength yang dibuat berdasarkan klasifikasi character strength yaitu kearifan dan pengetahuan, keteguhan hati, kemanusiaan dan cinta kasih, keadilan, kesederhanaan, transendensi. Untuk memperoleh data, penelitian ini menggunakan skala likert. Skala adalah perangkat pertanyaan yang disusun untuk mengungkap atribut tertentu melalui respon terhadap pertanyaan tersebut. Pada penelitian ini, skala pengukuran yang digunakan adalah skala kekuatan karakter. Dalam skala Likert terdapat pernyataanpernyataan yang terdiri atas dua macam, yaitu pernyataan yang favorable (mendukung atau memihak pada objek sikap), dan pernyataan yang unfavorable (tidak mendukung objek sikap). Dalam skala likert ini terdiri dari empat kategori jawaban, yakni : Sangat Sesuai (SS), Sesuai (S), Tidak Sesuai (TS), Sangat Tidak Sesuai (STS). Kategori netral tidak digunakan karena memiliki arti ganda yang dapat diartikan belum dapat memberikan jawaban atau netral, selain itu alternatif jawaban netral menyebabkan terjadinya central tendency affect (kecenderungan efek tengah - tengah), serta jawaban netral akan mengurangi banyaknya informasi yang bisa didapat dari responden [10]. Selain itu dilakukan uji Validitas, sejauh mana ketepatan dan kecermatan suatu alat ukur dalam melakukan fungsi ukurnya [12]. Suatu item dapat dianggap memiliki daya diskriminasi yang memuaskan jika berkorelasi signifikan terhadap skor total atau jika melakukan penilaian langsung terhadap koefisien korelasi bisa digunakan batas nilai berkriteria $\mathrm{r}_{\mathrm{xy}} \geq 0,3$ [12]. Data skala dikatakan memiliki daya beda tinggi jika koefisien korelasi lebih besar atau sama dengan $0,3\left(r_{x y} \geq 0,3\right)$ dan sebaliknya aitem skala dikatakan gugur jika koefisien korelasi lebih kecil dari $0,3\left(\mathrm{r}_{\mathrm{xy}} \geq 0,3\right)$.

\section{Hasil dan Pembahasan}

Peneliti menyebarkan 10 skala Character Strength dan meminta kesediaan kepada atlet anggota NPCI Kota Padang untuk mengisi skala. Peneliti telah memberikan petunjuk pengisian skala tersebut pada formulir dengan singkat dan jelas. 


\subsection{Hasil}

Koefisien Validitas skala Character Strength dengan nilai corrected item-total correlation berkisar antara 0,349 sampai dengan 0,831, dengan reabilitas 0,939, validitas skala Character Strength dengan nilai corrected item-total correlation berkisar antara 0,312 sampai dengan 0,746 , dengan reliabilitas 0,967 .

Tabel 1

Descriptive Statistic Skala Character Strength

\begin{tabular}{|l|r|r|r|r|r|}
\hline & \multicolumn{1}{|c|}{ N } & Minimum & Maximum & \multicolumn{1}{c|}{ Mean } & \multicolumn{1}{c|}{ Std. Deviation } \\
\hline $\begin{array}{l}\text { Character Strength } \\
\text { Valid N (listwise) }\end{array}$ & 10 & 228 & 267 & 245.90 & 14.910 \\
\hline
\end{tabular}

Dari tabel diatas dapat diketahui bahwa mean yang didapat adalah sebesar 245.90 dan standar deviasi sebesar 14.910. Nilai minmum yang didapatkan adalah 228 dan nilai maksimum adalah 267.

Tabel 2

Kategori Character Strength

\begin{tabular}{|c|c|c|c|c|}
\hline Variabel & Skor & Jumlah & Presentase (\%) & Kategori \\
\hline \multirow{2}{*}{$\begin{array}{c}\text { Character } \\
\text { Strength }\end{array}$} & $\mathrm{X}<231$ & 1 & $10 \%$ & Rendah \\
\cline { 2 - 5 } & $231 \leq \mathrm{X}<260$ & 7 & $70 \%$ & Sedang \\
\cline { 2 - 5 } & $260 \leq \mathrm{X}$ & 2 & $20 \%$ & Tinggi \\
\hline
\end{tabular}

Berdasarkan tabel diatas, diketahui bahawa variabel character strength diketahui bahwa mayoritas responden $70 \%$ atau 7 responden memiliki tingkat character strength sedang, $10 \%$ atau 1 responden memiliki tingkat character strength yang rendah, dan $20 \%$ atau 2 responden memiliki tingkat kekuatan karakter yang tinggi.

Tabel 3

Descriptive Statistic Klasifikasi Character Strength

\begin{tabular}{|l|r|r|r|r|r|}
\hline & $\mathrm{N}$ & \multicolumn{1}{|c|}{ Min } & \multicolumn{1}{c|}{ Max } & \multicolumn{1}{c|}{ Mean } & \multicolumn{1}{c|}{ Std. Deviation } \\
\hline Creativity & 10 & 3.00 & 3.67 & 3.2333 & .27442 \\
Curiosity & 10 & 2.00 & 3.50 & 3.0000 & .48591 \\
Open-Mindedness & 10 & 2.50 & 3.25 & 2.9500 & .25820 \\
Love of Learn & 10 & 2.50 & 3.50 & 3.0000 & .40825 \\
Perspective & 10 & 2.50 & 3.75 & 3.0750 & .40910 \\
Bravery & 10 & 2.50 & 3.50 & 2.8250 & .33437 \\
Persistence & 10 & 2.33 & 3.67 & 2.9333 & .43885 \\
Honesty & 10 & 2.25 & 3.75 & 3.0500 & .49721 \\
Vitality & 10 & 2.50 & 4.00 & 3.3000 & .43780 \\
Love & 10 & 2.00 & 3.50 & 2.8500 & .48876 \\
Kindness & 10 & 2.75 & 3.75 & 3.1000 & .33747 \\
Social Intelligence & 10 & 2.50 & 3.75 & 3.0500 & .34960 \\
Leadership & 10 & 2.00 & 3.50 & 2.8250 & .45720 \\
Fairness & 10 & 2.33 & 3.33 & 2.9000 & .35312 \\
Citizenship & 10 & 2.25 & 3.00 & 2.6250 & .24296 \\
Self Regulation & 10 & 2.25 & 3.50 & 2.9000 & .42817 \\
Prudence & 10 & 2.67 & 3.33 & 3.0667 & .26294 \\
Humility & 10 & 2.33 & 3.67 & 2.9667 & .36683 \\
Forgiveness & 10 & 2.33 & 4.00 & 3.2667 & .53978 \\
Appreciation & 10 & 2.50 & 4.00 & 3.5000 & .52705 \\
Gratitude & 10 & 2.67 & 4.00 & 3.3333 & .38490 \\
Hope & 10 & 3.00 & 4.00 & 3.4000 & .33747 \\
Humor & 10 & 2.00 & 3.00 & 2.5500 & .43780 \\
Spirituality & 10 & 2.00 & 4.00 & 3.4500 & .59861 \\
Valid N (listwise) & 10 & & & \\
\hline
\end{tabular}


Berdasarkan pengolahan data terhadap jawaban responden pada skala character strength diperoleh lima karakter tertinggi yaitu appreciation 3,50, selanjutnya spirituality 3,45, hope 3,40, gratitude 3,33 dan yang terakhir yaitu vitality dengan nilai rata-rata 3,30.

Tabel 4

Hasil Wawancara Character Strength

\begin{tabular}{|c|c|}
\hline Subjek & Respon \\
\hline $\mathrm{AI}$ & $\begin{array}{l}\text { Lama-lama bisa nerima aja seiring berjalannya waktu. Cuma keinginan sama semangat aja. } \\
\text { Abang kan pengen.. kan banyak teman-teman yang after injury itu abang pengen mereka } \\
\text { mencontoh juga gitu, jangan dirumah aja. Abang pengen jadi sample lah buat mereka gitu. }\end{array}$ \\
\hline AT & $\begin{array}{l}\text { Mungkin karena berfikir semua yang terjadi adalah kehendak dari Allah dan pasti ada } \\
\text { hikmah dibalik semua cobaan yang kakak terima. } \\
\text { Iya rizqa, mungkin kalau gak bisa menerima kak akan tetap berada di dalam kamar di } \\
\text { rumah kak, dengan mengunci diri sendiri, dan gak berani mengahadapi mata penuh tanya } \\
\text { dari orang lain }\end{array}$ \\
\hline FG & $\begin{array}{l}\text { Kakak ga ambil pusing. Jadi, intinya itu ada semangat dalam diri sendiri, punya semangat } \\
\text { tinggi, punya impian dan keinginan. Dengan kekurangan ini akak gak mau duduk meratapi } \\
\text { aja akak mau jadi contoh sama orang. Dibalik ini semua pasti ada hikmahnya. }\end{array}$ \\
\hline AS & $\begin{array}{l}\text { Apak gak terlalu mikirin kondisi ini, di jalani aja, diterima dan ikhlas. Selagi sehat ya.. } \\
\text { dinikmati aja }\end{array}$ \\
\hline $\mathrm{Y}$ & $\begin{array}{l}\text { Aa itu karena abang ikut organisasi itu, abang bertemu banyak orang disabilitas, banyak } \\
\text { yang lebih dari abang. Jadi abang udah menerima, abang pd dengan kondisi ini, abang } \\
\text { bangkit lagi setelah sama mereka. Dibalik kondisi seperti ini ada hikmahnya juga bagi } \\
\text { abang. }\end{array}$ \\
\hline S & $\begin{array}{l}\text { Kakak jalani itu } 5 \text { tahun, dari } 2001 \text { sampai } 2005 \text { akhir. Karena ada sakit apa di cubitus } \\
\text { luka tekan kan sering kontrol ke jamil disitulah akak liat ternyata lebih banyak orang yang } \\
\text { lebih parah dari akak aa disitulah mulai bangkit. Sebelumnya kan hanya dirumah merasa } \\
\text { kita sendiri yang terpuruk kan ha karna udah sering ke jamil kontrol kan liat ada banyak } \\
\text { orang yang lebih dari ini jadi kakak merasa kakak nggak harus seperti ini, mengurung } \\
\text { diri.. }\end{array}$ \\
\hline HP & ya dari atas, yakin.. sama yang diatas \\
\hline VP & $\begin{array}{l}\text { Ya walaupun keterbatasan, orang yang lebih parah dari kita aja banyak yang sukses } \\
\text { apalagi yang seperti abang, masih bisa kemana-mana. Masak orang bisa, kita nggak gitu } \\
\text { kan. }\end{array}$ \\
\hline AM & $\begin{array}{l}\text { Sabar aja.. } \\
\text { Masih ada yang diinginkan, masih ada yang mau dikejar gitu }\end{array}$ \\
\hline SB & $\begin{array}{l}\text { Dari } 2005 \text { sampai aa ... abang cuekin aja, pandangan mereka. Kalo abang kan baru awal } \\
\text { mulai kerja lagi abang digendong terus abang dapat kaki palsu, abang belajar jalan } \\
\text { sendiri, lama-lama abang bisa sendiri. Dengan kondisi abang seperti ini, abang malah } \\
\text { suka banget buat berbagi sama orang. Abang pernah di bilang naturalizer sama orang } \\
\text { luar, pemimpin yang alami. Cocok ndak? }\end{array}$ \\
\hline
\end{tabular}

\subsection{Pembahasan}

Berdasarkan pengolahan data terhadap jawaban responden pada skala character strength diperoleh lima karakter tertinggi yaitu appreciation 3,50, selanjutnya spirituality 3,45, hope 3,40, gratitude 3,33 dan yang terakhir yaitu vitality dengan nilai rata-rata 3,30. Sehingga dapat disimpulkan bahwa kekuatan karakter yang paling menonjol pada atlet penyandang tuna daksa di NPCI kota Padang adalah appreciation.

Individu yang memiliki kekuatan appreciation diasumsikan sebagai individu yang pikiran dan hatinya terbuka untuk sesuatu yang indah dan menawan biasanya akan lebih menikmati kehidupan sehari-hari, menemukan makna hidup dan dapat berhubungan dengan orang lain lebih mendalam [8]. Kekuatan ini yang digunakan para atlet untuk tetap dapat bangkit dan menemukan jati dirinya melalui komunitas NPCI ini. Apabila dibandingkan dengan hasil wawancara terhadap subjek, mayoritas subjek mengatakan bahwa setelah mereka bergabung dengan lingkungan sosial dimana terdapat banyak orang yang memiliki kondisi fisik seperti mereka malah membuat para atlet semakin kuat dan semakin bersemangat untuk mengembangkan kemampuan serta meraih tujuan mereka. 
Kekuatan karakter selanjutnya adalah kekuatan spiritual. Spirituality mengandung keyakinan yang bersifat persuasive, pervasive dan stabil yang membentuk atribusi individu dan bagaimana memaknai hidup dan hubungan dengan orang lain [8]. Kekuatan spiritual yang ada dalam diri mereka ini lah yang menuntun mereka untuk terus beribadah dan mengingat Tuhan disetiap situasi. Para Atlet yang memiliki kondisi fisik yang tidak sempurna beranggapan bahwa kondisi yang ada pada diri mereka adalah sebuah karunia yang diberikan oleh Tuhan kepada mereka yang kemudian mereka gunakan secara maksimal sebagai Atlet agar dapat berprestasi, hal tersebut merupakan suatu bentuk rasa syukur mereka atas karunia yang diberikan Tuhan kepada mereka, dan rasa syukur itu merupakan salah satu bentuk ibadah kepada Tuhan.

Subjek dalam penelitian ini juga memiliki kekuatan karakter hope atau harapan. Mengharapkan yang terbaik bagi masa depan dan berusaha keras untuk mewujudkannya, percaya bahwa nasib dapat diubah [8]. Para atlet mengaku bahwa mereka memiliki harapan yang besar untuk kehidupan mereka kedepannya walaupun dengan kondisi yang mereka alami saat ini. Kekuatan Karakter Gratitude (Syukur) merupakan salah satu kekuatan yang mereka gunakan untuk mendorong mereka menjadi atlet dan bertahan dalam menghadapi segala kondisi-kondisi yang kurang menguntungkan. Para Atlet memandang kondisi fisik yang ada dalam diri mereka sebagai karunia bukan sebagai kekurangan, dengan kondisi fisik mereka seperti ini lah mereka dapat menjadi seorang atlet. Fitzgerald [8] mengemukakan bahwa gratitude terdiri dari tiga komponen, yakni apresiasi terhadap seseorang dan sesuatu, niat yang baik kepada seseorang atau sesuatu, dan kecenderungan untuk bertingkah laku yang berasal dari apresiasi dan niat yang baik.

Kekuatan karakter lain yang dimiliki para atlet adalah vitalitas yaitu menjalani kehidupan dengan kegembiraan dan berenergi, tidak melakukan sesuatu setengah-setengah, menjalani hidup sebagai seorang petualang, merasakan hidup bahagia dan aktif [8]. Para atlet dalam menjalani hidupnya dipenuhi dengan semangat dan gairah. Walaupun dengan keterbatasan yang dimiliki, mereka menganggap bahwa kehidupan ini merupakan petualangan yang harus dinikmati.

\section{Kesimpulan}

Penelitian ini dilakukan pada 10 orang atlet penyandang tuna daksa di NPCI kota Padang. Berdasarkan pengolahan data yang telah dilakukan terdapat lima character strength yang menonjol atau disebut juga dengan signature strength, yaitu appreciation 3,50, selanjutnya spirituality 3,45, hope 3,40, gratitude 3,33 dan yang terakhir yaitu vitality 3,30.

\section{Daftar Rujukan}

[1] Muttaqin, Anandya Ikhwan \& Supraptiningsih, Endang. 2017. Character Strength Pada Atlet Penyandang Tuna Daksa Di Npci Kota Bandung. Journal of Psychological Research. Fakultas Psikologi Universitas Islam Bandung. Vol. 3, No. 1, Mei 2017: 58-68

[2] World Health Organization. 2011. World Report On Disability. Malta : WHO Library Cataloguing-in Publication Data: 28-29.

[3] InfoDatin. 2014. Pusat Data dan Informasi Kementrian Kesehatan RI : Penyandang Disabilitas Pada Anak. Indonesia : Kementrian Kesehatan RI

[4] Faruqi, Hasanan. 2018. Psychological Well - Being Pada Atlet Difabel. Publikasi Ilmiah. Universitas Muhammadiyah Surakarta.

[5] Setyaningrum, Maisun Luthfiani. 2018. Motivasi Berprestasi Pada Atlet Penyandang Tuna daksa Yang Mengikuti Paralympic Di Tenggarong. Jurnal Psikologi Fisip Psikoborneo. Universitas Mulawarman Samarinda. Vol. 6, No. 2, $2018: 510-519$

[6] Multahada, Erna. 2016. Peran Kekuatan Karakter Terhadap resiliensi Perawat (Studi Kasus Pada Perawat Di Rumah Sakit X). Jurnal Ilmu Ekonomi dan Sosial. Universitas Mercu Buana Jakarta. Vol 5, No 3, November 2016, 275-279.

[7] Ramdhan, Muhammad Dani \& Dewi Sartika. 2015. Hubungan Character Strength dengan Employee Engagement pada kelompok kerja reporter stasiun RRI Bandung. Jurnal Psikologi. Universitas Islam Bandung. ISSN: 2460-6448

[8] Peterson dan Seligman. 2004. Character strengths and virtues: A handbook and classification. Washington, DC: American Psychological Association. 
[9] Pratiwi, Imelda \& Hartosujono. 2014. Resiliensi Pada Penyandang Tuna Daksa Non Bawaan. Jurnal Spirits. Vol.5, No.1, November 2014. ISSN: 2087-7641

[10]Margareta, Shinta. 2013. Hubungan Pelaksanaan Sistem Kearsipan Dengan Efektivitas Pengambilan Keputusan Pimpinan. Bandung : Universitas Pendidikan Indonesia

[11] Sugiyono. 2014. Metode Penelitian Pendidikan Pendekatan Kuantitatif, Kualitatif, dan R\&D. Bandung: Alfabeta.

[12] Azwar, Saifuddin. 2014. Penyusunan Skala Psikologi. Yogyakarta : Pustaka Pelajar. 